\title{
AKTIVITAS ANTIOKSIDAN, TOTAL FENOL, DAN KADAR VITAMIN C DARI KOMBUCHA DAUN SALAM (Syzygium polyanthum (Wight) Walp.)
}

\author{
Sitaresmi Yuningtyas ${ }^{1 *}$, Eem Masaenah ${ }^{1}$, Murniwati Telaumbanua ${ }^{1}$ \\ ${ }^{1}$ Program Studi Farmasi, Sekolah Tinggi Teknologi Industri dan Farmasi Bogor, Jalan Kumbang \\ No. 23, Bogor, Indonesia, 16151 \\ Korespondensi: sitaresmi.yuningtyas@gmail.com
}

\begin{abstract}
ABSTRAK
Kombucha adalah hasil fermentasi teh dan gula oleh SCOBY (symbiotic culture of bacteria and yeast). Kombucha dapat dibuat dari daun yang tinggi fenol salah satunya adalah daun salam. Penelitian ini bertujuan menentukan aktivitas antioksidan, total fenol, dan kadar vitamin C dari kombucha daun salam. Pada penelitian ini menggunakan kombucha daun salam dibuat dengan konsentrasi 12,5; 25; 37,5; dan $50 \mathrm{~g} / \mathrm{l}$. Kombucha daun salam yang diperoleh di uji karakteristik kombucha daun salam meliputi uji fitokimia, $\mathrm{pH}$ serta pengujian aktivitas antioksidan, total fenol dan kadar vitamin $\mathrm{C}$ secara in vitro. Aktivitas antioksidan kombucha daun salam pada penelitian ini diperoleh 38,58\%-75,05\% dengan nilai $\mathrm{IC}_{50}$ sebesar $27 \mathrm{~g} / \mathrm{l}$, total fenol kombucha daun salam berkisar 4,74-51,972 ppm, dan kadar vitamin C antara 16,426-30,506 mg/100g. Berdasarkan uji total fenol, kadar vitamin $\mathrm{C}$ dan uji antioksidan maka kombucha daun salam memiliki aktivitas antioksidan.
\end{abstract}

\section{Kata kunci : antioksidan, daun salam, kombucha.}

\begin{abstract}
Kombucha is the result from fermentation of tea and sugar by SCOBY (symbiotic culture of bacteria and yeast). Kombucha can be made from leaves that are high ini phenol for example is bay leaves. This research aims to determine the antioxidant activity, total phenol, and vitamin $\mathrm{C}$ levels of bay leaves kombucha. Bay leaves kombucha were prepared with concentrations of $12.5 ; 25 ; 37.5$; and 50 $\mathrm{g} / \mathrm{l}$. Bay leaves kombucha obtained will be tested for the characteristics including phytochemical compounds and $\mathrm{pH}$ tests. In addition, it is also carried out for testing antioxidant activity, total phenol and vitamin $\mathrm{C}$ levels by in vitro. The antioxidant activity of bay leaves kombucha was $38.58 \%$ $75.05 \%$ with an IC 50 value of $27 \mathrm{~g} / \mathrm{l}$, total phenol of bay leaves kombucha were 4.74-51.972 ppm and levels of vitamin $\mathrm{C}$ were $16.426-30.506 \mathrm{mg} / 100 \mathrm{~g}$. Based on the total phenol test, vitamin $\mathrm{C}$ levels and antioxidant test, the bay leaves kombucha had antioxidant activity.
\end{abstract}

\section{Keywords: antioxidants, bay leaves, kombucha.}

\section{PENDAHULUAN}

Kombucha diperoleh dari teh serta gula yang difermentasi oleh SCOBY (symbiotic culture of bacteria and yeast) pada suhu ruang selama 7-14 hari. Simbiosis kultur yang digunakan pada kombucha [1]. Bakteri asam asetat seperti Acetobacter xylinoides, Acetobacter pasteurianus, Acetobacter xylinum, Acetobacter aceti, dan Bacterium gluconicum digunakan sebagai kultur untuk kombucha. Selain itu, khamir yang digunakan untuk fermentasi kombucha seperti Kloeckera apiculata, Brettanomyces lambicus, Brettanomyces bruxellensis, Brettanomyces custersii, Candida, Schizosaccharomyces pombe, Saccharomyces cerevisiae, Saccharomycodes ludwigii, Zygosaccharomyces bailii, dan Pichia sp. [2].

Pada proses fermentasi kombucha, glukosa akan difermentasi oleh khamir dan bakteri sehingga dapat dihasilkan alkohol dan asam-asam organik. Komponen mayor pada kombucha dalah etanol, asam asetat, dan asam glukoronat. Selain itu, terdapat komponen minor pada kombucha yaitu asam laktat, asam fenolat, enzim, dan vitamin B [2]. Proses fermentasi kombucha menghasilkan metabolit asam sitrat, asam tartarat, asam malonat, asam oksalat, asam suksinat, asam piruvat, vitamin B kompleks, mineral, asam askorbat, asam amino, purin, dan 
antibiotik. Minuman kombucha memiliki manfaat meningkatkan sistem imun, melancarkan pencernaan, mencegah kanker dan penyakit jantung, antimikroba, agen hipoglikemia dan hiperlipidemia, antioksidan [3].

Daun yang mengandung fenol dapat dimanfaatkan sebagai sumber untuk pembuatan kombucha. Salah satunya adalah daun salam (Syzygium polyanthum (Wight) Walp.). Daun salam mengandung minyak atsiri, tanin, triterpenoid, seskuiterpen, fenol, saponin, lakton, steroid, sitral, dan karbohidrat yang berpotensi menghasilkan aktivitas antioksidan [4]. Pemanfaatan daun salam sebagai bahan baku pembuatan kombucha belum pernah dilakukan. Berdasarkan hal tersebut, penelitian ini bertujuan menentukan aktivitas antioksidan, total fenol, dan kadar vitamin $\mathrm{C}$ dari kombucha daun salam.

\section{METODE PENELITIAN}

Bahan : daun salam (Syzygium polyanthum (Wight) Walp. yang berasal dari BALITRO, kultur kombucha (Acetobacter xylinum, Brettanomyces, Zygosaccharomyces, dan Saccharomyces cerevisiae), pereaksi Meyer, pereaksi Dragendroff, pereaksi Wagner, DPPH (2,2-difenil-1-1 pikrilhidrazil), $\mathrm{Mg}, \mathrm{HCl}$ pekat, $\mathrm{FeCl}_{3}$, Vitamin $\mathrm{C}, \mathrm{HCl} 2 \mathrm{~N}, \mathrm{CHCl}_{3}$, asam asetat anhidrida, $\mathrm{H}_{2} \mathrm{SO}_{4}$ pekat, pereaksi fenolftalein, $\mathrm{NaOH} 0,1 \mathrm{~N}$, metanol, asam galat (Sigma), $\mathrm{Na}_{2} \mathrm{CO}_{3} 75 \%$, Reagen Folin-Ciocalteau (merk 1.09001.0500), akuades, natrium karbonat $75 \%$, amilum $1 \%$, dan iodium $0,01 \mathrm{~N}$.

Alat: alat gelas, toples kaca, kain penutup toples, panci stainlees steel, karet perekat, $\mathrm{pH}$ meter, spektrofotometri UV-Vis (Shimadzu Series UV mini-1240), timbangan digital (ACIS), dan inkubator.

\section{Metode}

\section{Pembuatan Kombucha Daun Salam}

Kombucha daun salam dibuat dengan cara simplisia daun salam ditimbang lalu ditambahkan air sehingga memperoleh konsentrasi 12,5; 25; 37,5; dan 50 g/l. Campuran direbus selama 15 menit pada suhu $80^{\circ}$. Kemudian air rebusan disaring kemudian ditambahkan gula $10 \%(\% \mathrm{~b} / \mathrm{v})$. Filtrat rebusan daun salam didinginkan sampai suhu $\pm 25^{\circ} \mathrm{C}$. Kemudian filtrat rebusan ditambahkan starter kombucha (SCOBY) sebanyak 100 g/L. Sampel ditutup dengan kain serta diikat dengan karet untuk menghindari kontaminasi udara, serta selanjutnya dilakukan proses fermentasi selama 8 hari pada suhu ruang. Kombucha daun salam yang diperoleh diuji penapisan fitokimia secara kualitatif, uji pH, uji antioksidan, uji total fenol, dan uji kadar vitamin $C$ [5].

\section{Penapisan Fitokimia}

Kombucha daun salam dilakukan uji fitokimia berupa uji kualitatif golongan flavonoid, alkaloid, tanin, saponin, terpenoid, dan steroid [6].

Uji Alkaloid. Sebanyak $5 \mathrm{ml}$ sampel ditambahkan $1 \mathrm{ml}$ asam klorida $2 \mathrm{~N}$ serta $10 \mathrm{ml}$ air. Campuran dipanaskan pada penangas air selama 2 menit. Selanjutnya campuran didinginkan kemudian disaring. Filtrat dibagi menjadi 3 tabung reaksi. Pada tabung pertama dimasukkan pereaksi Mayer, pada tabung kedua dimasukkan perekasi Dragendorff, dan pada tabung ketiga dimasukkan pereaksi Wagner.

Uji Flavonoid. Sebanyak $5 \mathrm{ml}$ sampel dipanaskan selama 5 menit setelah itu sampel disaring. Filtrat yang diperoleh kemudian ditambahkan serbuk magnesium serta HCl:etanol (1:1) dan amil alkohol. Adanya senyawa golongan flavonoid ditandai dengan terbentuknya endapan warna jingga hingga merah ungu.

Uji Saponin. Sampel dimasukkan ke dalam tabung reaksi sebanyak $5 \mathrm{ml}$ kemudian sampel dilakukan pengocokan kuat. Jika terbentuk busa yang stabil maka sampel tersebut mengandung saponin.

Uji Tanin. Sebanyak $5 \mathrm{ml}$ sampel ditetesi $\mathrm{FeCl}_{3}$ $1 \%$. Adanya tanin ditandai dengan munculnya warna biru kehitaman atau hijau kecoklatan.

Uji Steroid. Sebanyak $5 \mathrm{ml}$ diuapkan dalam cawan penguap. Residu dilarutkan dengan 0,5 $\mathrm{ml}$ kloroform, ditambahkan $0,5 \mathrm{ml}$ asam asetat anhidrat, dan $2 \mathrm{ml}$ asam sulfat pekat melalui dinding tabung. Terbentuknya cincin cokelat atau violet pada perbatasan larutan menunjukkan adanya triterpenoid, sedangkan bila muncul cincin biru kehijauan menunjukkan adanya steroid.

\section{Penetapan pH}

Alat $\mathrm{pH}$ meter dilakukan kalibrasi terlebih dahulu dengan buffer $\mathrm{pH} 4$ dan $\mathrm{pH} 7$. Selanjutnya elektroda $\mathrm{pH}$ meter dicelupkan kedalam $10 \mathrm{ml}$ sampel [7].

\section{Penetapan Aktivitas Antioksidan}

Sebanyak $2 \mathrm{ml}$ kombucha daun salam dimasukkan kedalam tabung reaksi lalu ditambahkan dengan 0,1 mM DPPH (2,2difenil-1-1 pikrilhidrazil) sebanyak $2 \mathrm{~mL}$. 
Selanjutnya campuran diinkubasi pada suhu ruang selama 30 menit dan dihitung serapannya dengan spektrofotometer UV-Vis pada panjang gelombang $515,5 \mathrm{~nm}$. Persentase inhibisi dihitung dengan rumus sebagai berikut.

Daya inhibisi $(\%)=\frac{\text { Abs blanko-Abs sampel }}{\text { Abs blanko }} \times 100 \%$

Keterangan :

Abs blanko $=$ absorbansi tidak mengandung sampel

abs sampel $=$ absorbansi sampel

Penentuan $\mathrm{IC}_{50}$ (Inhibition Concentration 50) ditentukan dengan memplotkan persentase inhibisi yang diperoleh kedalam persamaan regresi $\mathrm{Y}=\mathrm{a}+\mathrm{bx}$ dimana $\mathrm{x}$ adalah konsentrasi larutan uji (g/l) dan y adalah nilai \% inhibisi [8].

\section{Penetapan Kadar Total Fenol}

Sebanyak $1 \mathrm{~mL}$ sampel kombucha daun salam dipipet ke dalam tabung reaksi lalu ditambahkan reagen Folin-Ciocalteau sebanyak $5 \mathrm{~mL}$. Campuran didiamkan selama 5-8 menit. Sebanyak $4 \mathrm{ml} \mathrm{Na}_{2} \mathrm{CO}_{3} \quad 75 \%$ ditambahkan hingga larutan berwarna biru lalu didiamkan selama 2 jam diruang gelap. Selanjutnya campuran diukur absorbansinya dengan spektrofotometer UV-Vis pada panjang gelombang 743,5 nm. Hasil pengukuran absorbansi diplotkan pada kurva standar asam galat [9].

\section{Penetapan Kadar Vitamin C}

Sebanyak 5 gram kombucha daun salam dimasukkan ke labu takar lalu diencerkan dengan akuades hingga $100 \mathrm{ml}$. Sampel kombucha yang sudah diencerkan kemudian diambil sebanyak $25 \mathrm{~mL}$ dan dimasukkan ke dalam erlenmeyer. Selanjutnya sampel ditambah $2 \mathrm{~mL}$ indikator amilum $1 \%$ lalu dititrasi dengan iodium 0,01 $\mathrm{N}$ sampai berwarna biru [10]. Penghitungan kandungan vitamin $\mathrm{C}$ menggunakan rumus sebagai berikut.

Kadar Vitamin $\mathrm{C}=\frac{A \times 0,88 \times F P}{W}$

Keterangan :

Kadar vitamin C (mg/100 g)

$\mathrm{A}=$ volume iodium yang dipakai untuk titrasi (ml)

$0,88=0,88 \mathrm{mg}$ asam askorbat setara dengan 1 $\mathrm{ml}$ larutan $\mathrm{I}_{2} 0,01 \mathrm{~N}$

$\mathrm{FP} \quad=$ Faktor pengenceran

$\mathrm{W} \quad=$ Berat sampel $(\mathrm{mg})$

\section{Analisis Data}

Nilai $\mathrm{pH}$, nilai persentase inhibisi, nilai total fenol dan kadar vitamin C tiap sampel di analisis dengan Rancangan Acak Lengkap dengan one way ANOVA. Uji lanjut dengan uji Duncan. Analisis dengan menggunakan aplikasi SPSS (Statistical Product and Service Solution) 16.

\section{HASIL DAN PEMBAHASAN Kandungan Fitokimia Kombucha Daun Salam}

Hasil uji fitokimia yang diperoleh pada kombucha daun salam mengandung flavonoid, saponin, tanin dan polifenol. Daun salam mengandung flavonoid, tanin, saponin, seskuiterpen, minyak atsiri, fenol, triterpenoid, sitral, steroid, saponin, lakton, karbohidrat, selenium, vitamin $\mathrm{A}$, vitamin $\mathrm{E}$, vitamin $\mathrm{C}$, dan niasin [4]. Komponen ini menunjang proses fermentasi kombucha daun salam.

\section{Nilai pH Kombucha Daun Salam}

Nilai pH kombucha daun salam pada kisaran pH 2,79-3,22 (Gambar 1). Nilai pH kombucha daun salam sesuai dengan standar $\mathrm{pH}$ kombucha yaitu 2,5 hingga 4,5 [11]. Penurunan $\mathrm{pH}$ pada kombucha disebabkan oleh proses fermentasi oleh SCOBY. Sel khamir pada SCOBY akan menghidrolisis sukrosa menjadi glukosa dan fruktosa dengan enzim invertase. Proses ini juga menghasilkan etanol. Acetobacteria pada SCOBY menggunakan glukosa dan etanol untuk membentuk asam glukonat dan asam asetat. Glukosa dapat ditransformasi menjadi asam glukonat melalui reaksi oksidasi pada C-6 glukosa. Bakteri asam laktat pada SCOBY memfermentasi glukosa dan sukrosa menjadi asam laktat [12]. Pada proses fermentasi kombucha menghasilkan metabolit asam sitrat, asam tartarat, asam malonat, asam oksalat, asam suksinat, asam piruvat, vitamin B kompleks, mineral, asam askorbat, asam amino, purin, dan antibiotik [13].

Nilai kombucha daun salam semakin rendah seiring dengan rendahnya konsentrasi daun salam. Nilai $\mathrm{pH}$ kombucha daun salam berbeda nyata $(\alpha<0,05)$ antar perlakuan artinya ada pengaruh nyata dari kosentrasi daun salam terhadap $\mathrm{pH}$ kombucha yang dihasilkan. Hal ini menunjukkan adanya pengaruh jumlah konsentrasi daun terhadap $\mathrm{pH}$ yang terbentuk. Semakin tinggi konsentrasi daun salam maka metabolit sekunder seperti flavonoid dan tanin semakin tinggi. Jika flavonoid dan tanin tinggi maka dapat menyebabkan terhambatnya pertumbuhan mikroorganisme bahkan kematian. 
Tanin dapat menyebabkan kerusakan dan peningkatan permeabilitas sel bakteri sehingga pertumbuhan sel terhambat [14]. Oleh sebab itu, semakin tinggi konsentrasi daun salam maka bakteri dan khamir dapat terhambat pertumbuhannya maka dapat berakibat produk yang terbentuk seperti asam organik terhambat.

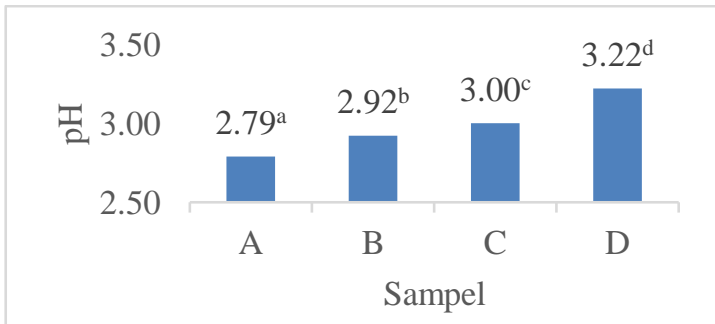

Gambar 1. Nilai pH dari kombucha daun salam

Keterangan:

A: kombucha daun salam 12,5 g/l

B: kombucha daun salam $25 \mathrm{~g} / \mathrm{l}$

C: kombucha daun salam 37,5 g/l

D: kombucha daun salam $50 \mathrm{~g} / \mathrm{l}$

Notasi huruf yang berbeda menunjukkan perbedaan signifikan (berdasarkan uji one way ANOVA dan dilanjutkan dengan post Hoc Test Duncan).

\section{Aktivitas Antioksidan, Total Fenol dan Kadar Vitamin C dari Kombucha Daun Salam}

Aktivitas antioksidan, total fenol, dan kadar vitamin $\mathrm{C}$ kombucha daun salam meningkat seiring dengan peningkatan konsentrasi daun salam (Tabel 1). Potensi menghambat radikal bebas DPPH merupakan salah satu indikasi bahwa kombucha daun salam memiliki aktivitas antioksidan. Rerata aktivitas antioksidan produk kombucha daun salam pada berbagai konsentrasi daun salam adalah $38,58 \%-75,05 \%$. Nilai $\mathrm{IC}_{50}$ (Inhibition Concentration 50) dari kombucha daun salam adalah $27 \mathrm{~g} / \mathrm{l}$. Kadar total fenol kombucha daun salam pada kisaran 4,70451,972 ppm. Kadar vitamin $\mathrm{C}$ kombucha daun salam yaitu $16,426-30,506 \mathrm{mg} / 100 \mathrm{~g}$. Analisis ragam menyatakan bahwa terdapat perbedaan nyata $(\alpha<0,05)$ pada aktivitas antioksidan dan kadar fenol. Hal ini menunjukan bahwa ada pengaruh yang nyata dari konsentrasi daun salam terhadap aktivitas antioksidan dan total fenol.

Tabel 1. Daya inhibisi DPPH, total fenol, dan kadar vitamin C pada kombucha daun salam

\begin{tabular}{llccc}
\hline No & \multicolumn{1}{c}{ Sampel } & $\begin{array}{c}\text { Daya Inhibisi } \\
\text { DPPH (\%) }\end{array}$ & $\begin{array}{c}\text { Total Fenol } \\
(\mathbf{p p m})\end{array}$ & $\begin{array}{c}\text { Kadar Vitamin C } \\
(\mathbf{m g} / \mathbf{1 0 0 g})\end{array}$ \\
\hline 1 & Kombucha daun salam 12,5 g/l & $38,58^{\mathrm{a}}$ & $4,704^{\mathrm{a}}$ & $16,426^{\mathrm{a}}$ \\
2 & Kombucha daun salam 25 g/1 & $46,83^{\mathrm{b}}$ & $18,638^{\mathrm{b}}$ & $25,813^{\mathrm{b}}$ \\
3 & Kombucha daun salam 37,5 g/l & $55,65^{\mathrm{c}}$ & $37,805^{\mathrm{c}}$ & $28,160^{\mathrm{b}}$ \\
4 & Kombucha daun salam 50 g/1 & $75,05^{\mathrm{d}}$ & $51,972^{\mathrm{d}}$ & $30,506^{\mathrm{b}}$ \\
\hline
\end{tabular}

Notasi huruf yang berbeda pada kolom yang sama, menunjukkan perbedaan signifikan

Peningkatan aktivitas antioksidan dan total fenol pada kombucha daun salam disebabkan proses metabolisme mikroorganisme saat proses fermentasi. Pada saat fermentasi kombucha, mikroorganisme dapat meningkatkan pembentukan senyawa polifenol [13]. Khamir memiliki kemampuan menghasilkan enzim asam ferulat reduktase dan enzim vinil fenol reduktase sehingga terjadi proses dekarboksilasi asam sinamat dan asam firulat menghasilkan senyawa polifenol pada fase stasioner [15]. Daun salam sebagai bahan baku kombucha mengandung senyawa golongan fenol. Senyawa golongan fenol ini dapat meningkat seiring dengan proses (berdasarkan uji one way ANOVA dan dilanjutkan dengan post Hoc Test Duncan).

fermentasi kombucha sehingga aktivitas antioksidan dan total fenol meningkat [14].

Flavonoid yang terkandung dalam daun salam adalah katekin, kuersetin, mirisetin, baikalein, dan karvakrol [16]. Senyawa-senyawa tersebut berperan dalam aktivitas antioksidan. Salah satunya adalah isomer epikatekin yaitu epikatekin, epikatekin galat, epigalokatekin, dan epigalokatekin galat. Keempat senyawa tersebut mengalami proses biotransformasi oleh mikroorganisme SCOBY. Epigalokatekin galat mengalami biotransformasi menjadi epigalokatekin dan epikatekin galat. Mikroorganisme pun melepaskan katekin ke dalam filtrat kombucha. Oleh karena itu, proses 
14 | Sitaresmi Yuningtyas et al.,( Aktivitas Antioksidan, Total Fenol, Dan Kadar...)

tersebut dapat meningkatkan komponen polifenol selama fermentasi [17].

Kadar vitamin C pada kombucha daun salam meningkat seiring dengan meningkatnya konsentrasi daun salam. Selama fermentasi kombucha daun salam, terjadi biotransformasi gula sederhana menjadi vitamin C. Proses ini disebabkan oleh enzim yang dihasilkan Acetobakter xylinum. Glukosa direduksi menjadi D-sorbitol. Senyawa D-sorbitol yang terbentuk diubah menjadi L-sorbosa lalu L-sorbosa mengalami oksidasi kimia menghasilkan asam 2-keton-L-gulomat. Selanjutnya asam 2-ketonL-gulomat difermentasi menjadi asam 2-Laskorbat [3]. Proses tersebut membuat kadar asam askorbat (vitamin C) pada kombucha daun salam semakin meningkat

\section{SIMPULAN}

Kombucha daun salam memiliki potensi sebagai antioksidan secara in vitro. Aktivitas antioksidan kombucha daun salam berkisar $38,58 \%-75,05 \%$ dengan nilai $\mathrm{IC}_{50}$ sebesar $0,0270 \mathrm{~g} / \mathrm{ml}$. Total fenol kombucha daun salam kisaran 4,740-51,972 ppm dan kadar vitamin C antara 16,426-30,506 mg/100 g. Oleh karena itu, kombucha daun salam memiliki potensi antioksidan.

\section{DAFTAR PUSTAKA}

[1] M. Malbasa, R., Loncar, E., Djuric. 2008. Comparison of the products of Kombucha fermentation on sucrose and molasses. Food Chem. 3: 1039-1045.

[2] Chen, C., Liu, B.Y. 2000. Changes in major components of tea fungus metabolites during prolonged fermentation. J. Appl. Microbiol. 89 (5): 834-839.

[3] Dutta, H., Paul, S.K. 2019. Kombucha Drink: Production, Quality, and Safety Aspects. New York: Elsevier Inc., 2019.

[4] Agoes, A. 2010. Tanaman Obat Indonesia. Jakarta: Salemba Medika.

[5] Suhardini, P., N., Zubaidah, E. 2016. Studi Aktivitas Antioksidan Kombucha Dari Berbagai Jenis Daun Selama Fermentasi. J. Pangan dan Agroindustri 4 (1): 221-229.

[6] Sivanandham, V. 2015. Phytochemical techniques - a review. World J. Sci. Res 1 (2): 80-91.
[7] Setianto, Y.C., Pramono, Y. B., Mulyani, S. 2014. Nilai $\mathrm{pH}$, Viskositas, dan Tekstur Yoghurt Drink dengan Penambahan Ekstrak Salak Pondoh ( Salacca zalacca). Apl. Teknol. Pangan 3 (3): 110-113..

[8] Aqil, F., Ahmad, I., Mehmood, Z. 2006. Antioxidant and free radical scavenging properties of twelve traditionally used Indian medicinal plants. Turkish J. Biol. 30 (3): 177-183.

[9] Chaovanalikit, R. E., Wrolstad, A. 2004. Total Anthocyanins and Total Phenolics of Fresh and Processed Cherries and Their Antioxidant Properties. J. Food Sci. 69 (1): $67-72$.

[10] Sudarmaji, S., Haryono, B. 2007. Analisa Bahan Makanan dan Pertanian. Yogyakarta: Liberty.

[11] Nummer., B.A. 2013. Kombucha-Brewing Under The FDA Code. J. Environ. Health 76 (4): 8-11.

[12] Sreeramulu, K.W, Zhu Y., G. 2000. Kombucha Fermentaion and It's Antimicrobial Activity. J. Agric. Food Chem. 48 (6): 2589-2594.

[13] Jayabalan, R., Malbaša, M., V., Lončar, E., S., Vitas, J. S., Sathishkumar, M. 2014. A review on kombucha tea-microbiology, composition, fermentation, beneficial effects, toxicity, and tea fungus. Compr. Rev. Food Sci. Food Saf. 13 (4): 538-550.

[14] Ismail, A., Wan Ahmad, W. A., N. 2019. Syzygium polyanthum (Wight) Walp: A potential phytomedicine. Pharmacogn. J. 11 (2): 429-438.

[15] Naczk, F., Shahidi, M. 2004. Extraction and analysis of phenolics in food. $J$. Chromatogr. A 1054 (1-2) : 95-111.

[16] Górniak, I., Bartoszewski, R., Króliczewski, K. 2019. Comprehensive review of antimicrobial activities of plant flavonoids. Phytochemistry Reviews 18: 241-272.

[17] Sukmawati, P., P., A., Ramona, Y., Leliqia, N. P. E. 2012. Penetapan Aktivitas Antioksidan yang Optimal pada the Hitam Kombucha J. Farm. Udayana 2 (1): 25-29 . 